\title{
Community Participants in Managing Education Programs in Vocational School
}

\author{
Claudia Nurlaiva \\ Department of Educational Administration \\ State University of Malang, Indonesia \\ raden.bambang.fip@um.ac.id
}

\author{
Raden Bambang Sumarsono \\ Department of Educational Administration \\ State University of Malang, Indonesia \\ raden.bambang.fip@um.ac.id
}

\begin{abstract}
This study aims to describe: (1) the components of society that participate in the implementation of educational programs; (2) the forms of community participation in education activities; and (3) the strategy of the principal in increasing community participation. The method used is qualitative, phenomenological approach, with a case study design in Private Vocational School 1 Muhammadiyah Malang (SMK 1 Muhammadiyah Malang). Data or facts collected using 3 techniques, namely: in-depth interviews, participant observation, and documentation studies. Data or information obtained through in-depth interviews was conducted by digging information from key informants, and several other informants. Meanwhile documentation study was carried out by investigating or reviewing the documents of community participation in the implementation of education programs. While the acquisition of data through observation techniques is done by observing several school activities involving the community. The analysis technique used is single case analysis. To obtain data validity, researchers conducted triangulation activities, checking members, observing perseverance, and the adequacy of reference materials. The results of the study include: (1) elements of the community involved or participating in the implementation of educational programs include: parents of students; community leaders and religious leaders, business and industry, academics, namely lecturers; health workers, police, and various other elements of society; (2) forms of community participation in the implementation of educational programs including education funding from parents, provision of scholarships from the business world / industrial world for disadvantaged students, provision of industrial practice, development school buildings, and the provision of other facilities and infrastructure; and (3) the principal's strategy in increasing community participation by: fostering trust in parents and the community, involving parents and communities in implementing school programs, establishing effective communication with the community, and building a climate conducive school.
\end{abstract}

Keywords: community component, participation form, improvement strategy, education program

\section{INTRODUCTION}

Education is a long-term investment that must always be improved and maintained in quality. Education is not only the responsibility of the government, but also the responsibility of parents and society. Community participation in schools can be interpreted as a contribution, contribution, involvement, participation, and community involvement in an effort to support the implementation of education programs in schools to achieve educational quality. Law Number 20 of 2003 concerning the National Education System article 54 states that community participation in education includes the participation of individuals, groups, families, professional organizations, entrepreneurs, and community organizations in the implementation and quality control of educational services. This implies that the participation of the community aims to utilize the capabilities of the community for education to realize the goals of education, especially in the era of school autonomy (with the implementation of School Based Management) today the role of the community is needed to support the smooth implementation of education programs in schools.

The relationship between school and community needs to be strengthened so that the responsibility of education is not only charged to schools. Communities must be actively invited to carry out educational programs. They must participate in determining and making programs with schools and the government. They must be active in learning and noninstructional activities. The community (parents) is expected to be able to provide time to visit schools and classes to control their children's education, discuss with teachers to find out the obstacles and progress faced by their children in the classroom. Nurkolis (2003) argues that there are two types of approaches for inviting parents and communities to actively participate in education, namely: (1) a school-based approach by inviting parents to come to school through meetings, conferences, and teacher-parent discussions and visit her child who is studying at school; and (2) home-based approach, that is, parents help their children learn at home.

Community participation should be considered by the school, especially the leadership of the principal so that its existence can be realized and maintained. So that ultimately the participation of the community is well maintained, thus it is possible that the school will not experience significant difficulties in developing various types of programs, because all parties have understood and feel responsible for the success of a program that will be developed by the school. Kusmintardjo (2010) states, that when there is a strong connection between school, family, and community, and involves actively assisting learning efforts and student development, then this will have a positive impact on education. Thus the shared responsibility of parents, communities and schools in improving the quality of education must not be ignored. The results of Preedy's (1993) study show that the involvement of parents in school activities has a positive effect on the progress and development of student learning. This indicates that academic and non-academic achievements will increase when there is participation from parents. Therefore, mobilization or empowering 
parental participation is expected to synergistically lead to one goal, namely improving the quality of education.

Schools and communities have a very close relationship in achieving school and education goals effectively and efficiently (Imron \& Sumarsono, 2017). Furthermore Wiyono (2010) asserted that the process of implementing education in schools will be able to succeed optimally, if supported by several parties, both resources from schools, parents, and the community. Therefore, the school is obliged to provide an explanation of the goals, programs, needs, and circumstances of the school to the community. Conversely, schools also need to know clearly what the needs, expectations, ideals, and demands of the community. The community is given the opportunity to play a role in the school program in order to achieve the vision and mission. In other words, between school and community must be fostered and developed a harmonious relationship. Wiyono (2010) argues, schools will not be able to provide education optimally, if they do not get support from parents and the community. By establishing a harmonious relationship between school and community, the quality of education will be realized.

Community participation in schools provides four important advantages, namely for students' achievement, providing resources to add and complete the existence of program opportunities, staff renewal and organizational innovation, and supporting politics. This is as stated by Keith \& Girling (1991) that community involvement in bringing benefits in four important areas: student achievement, incremental resources to supplement and complement the existing program opportunities for staff renewal and organizational innovation, and political support. The same thing was stated by Brody, Flor, and Gibson (1999) which stated that found parenting practices in students' increase in ability to self-regulate behavior.

Olsen and Fuller (2003) state that, the involvement of parents (community) in education will provide benefits for students themselves, communities, teachers, and schools. The benefits of parental involvement in education for students include: (1) students tend to get more benefits regardless of ethnicity and background of economic status, or education level of parents; (2) students generally achieve rank, value, and attendance better; (3) students consistently complete their homework; (4) students become more disciplined and show higher motivation to attend school; (5) positive attitudes of students towards school often provide results in the form of improvement in attitudes that improve in school and rarely violate applicable regulations; (6) students who are placed in remidial classes are reduced in number; (7) students who come from different cultures tend to do better if the parents and educators work together to bridge cultural differences that exist in the family and school environment; and (8) per students at the junior, senior high school, and equivalent level whose parents ask to be involved in school education programs usually make good transitions and are less likely to be expelled from school.
The benefits of parental involvement in education for parents include: (1) parents will try to increase interaction and discussion with their children, and become more responsive and sensitive to children's social, emotional, and intellectual development needs; (2) parents will be more confident in caring for their children; (3) because parents get the knowledge and understanding of their children's development, then parents will be better able to give love and reinforcement and reduce punishment for their children; (4) parents have a better understanding of the role of the teacher and the school curriculum; (5) when parents understand what their children are learning, they become more eager to help their children learn at home; (6) parents' concern for school increases and their determination and commitment to school is stronger; and (7) parents become more aware and become more $\mathrm{h}$ is active in giving attention and assistance to their child's education when asked by the school to take part in the decision making team.

The benefits of community involvement in education for teachers include: (1) teachers and principals will get higher moral values in the eyes of parents; (2) teachers and principals will receive a higher appreciation for their profession from the parents' side; and (3) consistently involving parents will improve communication and good relations between parents, teachers, and employees, (4) teachers and principals feel an increase in job satisfaction within them.

For schools, the benefits that can be drawn from parental involvement in education include: (1) schools that actively involve parents and communities tend to have a better reputation in the community; (2) schools have better support from the community; and (3) school programs that encourage and involve parents usually work better and have better quality programs than school programs that do not involve parents.

Judging from some of the benefits of involvement or community participation in education as described, it is fitting that schools seek to increase their participation so that the process of implementing education in schools will be optimal. Rhoda (in Nurkolis, 2003) suggests that family and community participation has many advantages, namely: (1) students' academic achievement and cognitive development significantly increase; (2) parents can know the development of their children in the process of education at school; (3) parents will be good teachers at home; and (4) parents have a positive attitude and outlook on school

Other research results by Castro, et al., (2015) which revealed that, parental involvement will lead to academic achievement of school children. The results of the study reinforce the results of a study from Levanda (2011), that parental involvement in schools has an impact on children's academic success. Meanwhile the involvement of parents in a particular arena of children's education has received multidimensional benefits (dedication of resources by parents to children in the education domain) and has a strong relationship to school achievement (Tan \& Golderberg, 2009; Porumbu \& Necsoi, 2013). Parental 
involvement will have an impact on positive academic achievement when parents enforce the rules at home and follow up at school to improve their child's academic success (Khajehpour, 2011).

Based on a study of the results of previous research and combined with phenomena that occur in the field, the researchers are interested in conducting a more in-depth study of the participation of the community in the implementation of educational programs in vocational secondary schools. Vocational high schools are chosen, because this type of school is in dire need of community involvement, especially the business world and the industrial world for the implementation of industrial work practices. The focus in this study will reveal about the components of society involved in the implementation of education programs, the form of their involvement, as well as the efforts of principals in increasing community participation.

\section{METHODS}

This study uses a qualitative approach with descriptive research design. The researcher adopted the opinion of Miles, Huberman, and Saldana (2014) \& Gunawan (2014) that the case as a phenomenon of some sort is occurring and a bounded context. Yin (2003) states an empirical inquiry case study that investigates a contemporary phenomenon within its real-life context, especially when the boundaries between phenomena and context are not clearly evident. Based on the design of the research conducted, the presence of researchers is very necessary because researchers act as key instruments in extracting information in depth and detail.

The study was conducted at SMK 1 Muhammadiyah Malang located at Galunggung Street, 37 A-B Malang City East Java Indonesia. Sources of data in this study use primary data and secondary data. Primary data includes digging up information from the principal. Meanwhile secondary data is documentation, where the document will then be analyzed and used as supporting evidence. Data or facts collected using 3 techniques, namely: in-depth interviews, participant observation, and documentation studies.

Data or information obtained through in-depth interviews was conducted by digging information from key informants, and several other informants. Meanwhile documentation study was carried out by investigating or reviewing the documents of community participation in the implementation of education programs. While the acquisition of data through observation techniques is done by observing several school activities involving the community. The analysis technique used is single case analysis. To obtain data validity, researchers conducted triangulation activities, checking members, observing perseverance, and the adequacy of reference materials.

\section{RESULTS AND DISCUSSION}

Components of the Community Involved in the Implementation of the Education Program

Components or elements of society involved in implementing education programs in SMK 1
Muhammadiyah Malang include: (1) parents of students; (2) community leaders and religious leaders around the school who have a major influence in the development of SMK 1 Muhammadiyah Malang; (3) business and industry, which is adjusted to the characteristics of the department in this school; (4) academics, namely lecturers around the Malang City who contribute ideas for school development; (5) health workers for health education for students; and (6) the police, for the dissemination of the dangers of drug use; and various other elements of society

Based on the results of the study indicate that elements of society participate in the implementation of educational programs in schools. Community involvement or participation has various benefits for the implementation of school education programs, including vocational high schools. Keith \& Girling (1991) stated that community involvement brings benefits in four important areas: student achievement, incremental resources to supplement and complement the existing program opportunities for renewal and organizational innovation staff, and political support. Meanwhile, Gorton \& Scheider (1991), suggested four reasons as well as the purpose of the need to involve the community in activities at school, one of which is that the community provides adequate support for equipment to support children's learning activities. Imron \& Sumarsono (2017), emphasizes that one of the benefits of community participation for schools is that schools will get better support and tend to have a better reputation in the community.

\section{Forms of Community Participation in the} Implementation of Educational Programs

The implementation of education in SMK 1 Muhamadiyah Malang is inseparable from the role of the community. Based on the results of the analysis obtained the forms of community participation are grouped into two forms namely physical and nonphysical. Forms of community roles in the form of physical, namely: (1) funding of education from parents of students; (2) provision of scholarships from the business world / industrial world for disadvantaged students; (3) provision of place of implementation of industrial practices; (4) construction of school buildings; and (5) provision of other facilities and infrastructure.

The findings of this study support the view of Zamroni (2000) which states the form of community participation in the implementation of education programs in schools related to fund mobilization efforts and concretely in the contribution of funds, materials, and labor. Furthermore (Depdiknas, 2002), it is argued that community participation can also be in the form of providing educational funding, providing assistance in academic development, providing assistance in nonacademic development, and providing assistance for the physical appearance of schools / madrasas.

Other community participation is realized in a non-physical form, namely: (1) participation in meetings held by the school; (2) the community as a learning resource; (3) submission of suggestions or criticism of the implementation of educational 
programs in schools that are inappropriate according to the community; (5) delivery of ideas or ideas in school development; (6) involved in solving school problems; and (7) become resource persons in implementing school activity programs.

The results of this study are in line with Ornstein \& Levine (1985) which states that parents can be involved in planning and solving problems in curriculum or learning programs, as well as policies on student affairs, as well as improving public relations programs. Their involvement can take the form of a partner, which can help prepare by identifying everything their children need when they will, during or even after attending school (Bacharach, 1990; Benty and Gunawan, 2015). The findings of other studies as expressed by Murillo (2002), that parental involvement are very important to improve the quality of education in schools. While Kimaro and Machumu (2015) through the results of their research stated that the finding is there is resistance of a positive and significant relationship between parental involvement in the school activities of their children and academic achievement. Castro, e.t all. (2015) through the results of the study revealed that, parental involvement will lead to academic achievement of school children. The results of this study reinforce the previous findings by Henderson \& Berla (1994), that the interaction between children and parents related to school things done at home will have an impact on children's achievement and independence. Imron \& Sumarsono (2017) argue, that the participation of the community in the development of education includes: (1) the delivery of ideas or ideas; (2) power; (3) property; and (4) education funding.

\section{Principal Strategy to Increase Community Participation in the Implementation of Education Programs}

The strategy carried out by the Head of SMK

1 Muhammadiyah Malang to increase community participation in the implementation of school programs, namely:

1. Fostering trust in parents and society. The school principal fosters trust in parents and society at large through: (a) the application of the principles of transparency and accountability in school management; and (b) the preparation of school programs based on community needs.

2. Involving parents and the community in implementing school programs. This strategy is carried out by: (a) the principal invites parents to report the development of their children's learning outcomes; and (b) involving the community in the preparation of the school activity program plan.

3. Establish effective communication with the community. This strategy is carried out by means of the intensity of communication, the use of social media to communicate.

4. Building a school climate that is conducive to the creation of intensity of community participation, one of which is done by fostering mutually beneficial cooperation.
The strategy of increasing community participation in the implementation of school programs, by Rohiat (2010) is interpreted as an effort to create an open and democratic environment where teachers, students, employees, and the community (parents of students) are encouraged to be directly involved in the implementation of education, starting from decision making, implementation, and evaluation which is expected to improve the quality of education in schools. The results of the study are in line with the thoughts of Imron and Sumarsono (2017), which states that there are several things that must be considered in seeking to increase community participation, including: (1) establishing effective communication with parents and the community; (2) involving the community and parents in implementation of school programs; (3) creating a conducive climate; (4) empowering the functions and roles of school committees; and (5) inviting communities at school annual meetings.

\section{CONCLUSION}

Based on the presentation of the research findings, the formulation of the research results is as follows: (1) elements of the community involved or participating in the implementation of education programs include: parents of students; community leaders and religious leaders, business and industry, academics, namely lecturers, health workers, police, and various other elements of society; (2) forms of community participation in the implementation of educational programs including education funding from parents, provision of scholarships from the business world / industrial world for disadvantaged students, provision of industrial practice, development school buildings, and the provision of other facilities and infrastructure; and (3) the principal's strategy in increasing community participation by: fostering trust in parents and the community, involving parents and the community in implementing school programs, establishing effective communication with the community, and building a climate conducive school.

\section{REFERENCES}

[1] Bacharach, S. B. 1990. Education Reform: Making Sense of it All. Boston: Allyn and Bacon.

[2] Benty, D. D. N., and Gunawan, I. 2015. Manajemen Hubungan Sekolah dan Masyarakat. Malang: Universitas Negeri Malang, UM Press.

[3] Brody, G. H., Flor, D. L., \& Gibson, N. M. 1999. Linking Maternal Efficacy Beliefs, Developmental Goals, Parenting Practices and Child Competence in Rural Single-Parent African American Families. Child Development, 70, 1197-1208.

[4] Castro, M., Casas, E., Martin, E., Lizasoain, L., Asencio, E., \& Gaviria, J. 2015. Parental Involvement on Student Academic Achievemnt: A Meta-Analysis. Education Research Review, 14, 33-46.

[5] Depertemen Pendidikan Nasional. 2002. Manajemen Peningkatan Mutu Berbasis Sekolah, Buku I. Jakarta: Ditjen Dikdasmen Depdiknas.

[6] Desforges, C., \& Abouchaar, A. 2003. The Impact of Parental Involvement, Parental Support and Family Education on Pupil Achievement and Adjustment: A 
Literature Review. Research Report the Department for Education and Skills. Retrieved January 12, 2018, from http://www.bgfl.org/bgfl/custom/

files_uploaded/uploaded.../Desforges.pdf.

[7] Eccles, J. S., \& Harold, R. D. 1993. Parent-School Involvement During the Early Adolescent Years. Teacher College Record, 94(3), 568-587.

[8] Gorton, R. A., \& Schneider, G. T. 1991. School-Based Leadership: Challenges and Opportunities. Dubuque: Wim. C. Brown Company Publisher.

[9] Gunawan, I. 2014. Metode Penelitian Kualitatif: Teori dan Praktik. Jakarta: PT Bumi Aksara.

[10] Hendersen, A. T., \& Berla, N. 1994. A New Generation of Evidence: The Family is Critical to Student Achievement. Washington, DC: National Commitee For Citizen in Education.

[11] Herman, J. L., \& Yeh, J. P. 1983. Some Effective of Parent Involment in School. Urban Review, 15(1), 1116.

[12] Imron, A., and Sumarsono, R. B. 2017. Manajemen Hubungan dan Partisipasi Masyarakat. Malang: UM Press.

[13] Keith, S., \& Girling, R. H. 1991. Educational, Management, and Participation: New Directions in Educational Administration. Boston: Allyn and Bacon.

[14] Khajehpour, M. 2011. Relationship between Emotional Intelegency, Parental Involvement, and Academic Performance at High School Student. Procedia Social and Behavior Science, 15, 1081-1086.

[15] Kimaro, A. R., \& Machumu, H. J. 2015. Impacts of Parental Involvement in School Activities on Academic Achievement of Primary School Children. International Journal of Education and Research, 3(8).

[16] Kusmintardjo. 2010. Manajemen Keterlibatan Orang Tua dalam Pendidikan. Manajemen Pendidikan, 23(2), 195-203).

[17] Levanda, O. 2011. Parental Involvement in School a Test of Hoover-Dempsey and Sandler's Model among Jewis and Arab Parent's in Israel. Childrees \& Youth Service Review, 33, 927-935.

[18] Milles, M. B., Huberman, M. A., \& Saldana, J. 2014. Qualitative Data Analysis: A Methods Sourcebook. Thousand Oaks, CA: Sage.

[19] Murillo, I. I. 2002. Good Effective School Improvement in Spain. Educational Research and Evaluation, 8(4), 387-410.

[20] Olsen, G., \& Fuller, M. L. 2003. Home-School Relations: Working Successfully with Parent and Families. Boston: Allyn and Bacon.

[21] Porumbu, D., \& Necsoi, D. V. 2013. Relationship between Parental Involvement, Attitude and Children's School Achievemnt. Procedia-Social and Behavior Science. 76, 706-710.

[22] Preedy, M. 1993. Managing The Effective School. London: The Open University.

[23] Reynolds, D., Bollen, R., Creemers, B., Hopkins, D., Stoll, L., \& Lagerwejj, N. 1996. Making Good Schools: Linking Schools Effectiveness and School Improvement. London: Routledge.

[24] Rohiat. 2010. Manajemen Sekolah: Teori Dasar dan Praktik. Bandung: PT Rafika Aditama.

[25] Shochib. M. 2010. Pola Asuh Orang Tua dalam Membantu Anak Mengembangkan Disiplin Diri. Jakarta: Rineka Cipta.

[26] Tan, E. T. \& Goldberg, W. A. 2009. Parental School Involvement in Relation to Children's Grades and Adaption to School. Journal of Applied Developmental Psychology, 30, 442-453.

[27] Undang-Undang Nomor 20 Tahun 2003 tentang Sistem Pendidikan Nasional. Bandung: Citra Umbara.
[28] Wiyono, B. B. 2010. Partisipasi Masyarakat terhadap Pelaksanaan Kegiatan Pendidikan. Manajemen Pendidikan, 23(1), (10-11).

[29] Yin, R. K. 2002. Case Study Research: Design and Methods. Thousand Oaks, CA: Sage.

[30] Zamroni. 2000. Paradigma Pendidikan Masa Depan. Yogyakarta: Biptaf Publishing. 